Pak. J. Agri. Sci., Vol. 53(2), 383-392; 2016

ISSN (Print) 0552-9034, ISSN (Online) 2076-0906

DOI: 10.21162/PAKJAS/16.3804

http://www.pakjas.com.pk

\title{
POTENTIAL PSYLLID VECTORS OF CANDIDATUS PHYTOPLASMA MALI AND CANDIDATUS PHYTOPLASMA PYRI IN TURKEY
}

\author{
Kamuran Kaya ${ }^{1}{ }^{*}$, Çigdem Ulubas Serce ${ }^{2}$, Mona Gazel ${ }^{1}$, Kadriye Caglayan $^{1}$ and Nicolas Sauvion ${ }^{3}$ \\ ${ }^{1}$ Mustafa Kemal University, Faculty of Agriculture, Plant Protection Department, Antakya/Hatay, Turkey; \\ ${ }^{2}$ Agricultural Science and Technology Faculty, Crop Production and Technologies Department, Nigde, Turkey; \\ ${ }^{3}$ INRA, Unite Mixte de Recherche Biologie et Genetique des Interactions Plante-Parasite, Montpellier, France. \\ *Corresponding author's e-mail: kayakamuran@gmail.com
}

\begin{abstract}
Psyllids are vectors of phytoplasma, which cause important diseases of pome fruit trees. Psyllid species reported as phytoplasma vectors were captured during 2010-2011 in several pome fruit growing regions in Turkey. Potential psyllid vectors of 'Candidatus Phytoplasma mali' were collected from Malus spp. (apple), Cydonia oblonga (quince), Crataegus spp. (hawthorn) and also from the overwintering hosts, whereas those of 'Candidatus Phytoplasma pyri' were collected from wild and cultured forms of Pyrus spp. (pear) trees. The psyllids were identified morphologically as Cacopsylla picta, C. melanoneura-C. affinis complex, C. crataegi, C. pyrisuga, C. pyri, C. pyricola and other Cacopsylla species. The highest natural phytoplasma infection rate was found in $C$. picta followed by $C$. pyri, C. melanoneura-C. affinis complex and $C$. crataegi with rates of 4.36, 3.84, 2.77 and $1.67 \%$, respectively. No phytoplasma were detected in C. pyrisuga, C. pyricola, or the other Cacopsylla spp. 'Ca. P. mali' was detected in C. picta, C. melanoneura-C. affinis complex and C. pyri; 'Ca. P. pyri' was detected in $C$. picta, $C$. crataegi, $C$. melanoneura-C. affinis complex and $C$. pyri individuals. To our knowledge, this is the first report on the possible psyllid vectors of ' $\mathrm{Ca}$. P. mali' in Turkey.
\end{abstract}

Keywords: Fruit tree diseases, apple proliferation, pear decline, epidemiology, Cacopsylla spp.

\section{INTRODUCTION}

Fruit tree diseases caused by phytoplasma have great economic effects on fruit production, especially in Europe. A major phytoplasma is 'Candidatus Phytoplasma mali', which causes apple proliferation (AP) disease mainly in cultured and wild forms of apple trees (Seemuller et al., 2011a); however, there has been a report of different hosts, including Prunus avium (L.) L., P. armeniaca L., and P.domestica L. (Mehle et al., 2007). 'Ca. Phytoplasma pyri' causes pear decline (PD) disease that is found mainly in cultured and wild forms of pear (Pyrus spp.) and quince (Cydonia oblonga Mill.) (Seemüller et al., 2011b). These phytoplasma are taxonomically classified into the $16 \mathrm{SrX}$ group (or AP-group) of phytoplasmas and constitute closely related subgroups (Seemüller and Schneider, 2004).

Phytoplasmas are mainly spread by vegetative propagation or the grafting of infected plant material and phloem feeding insects, primarily leafhoppers, planthoppers and psyllids (Weintraub and Beanland, 2006). Only one genus of this last one, Cacopsylla spp., transmit AP-group phytoplasmas to pome and stone fruit trees. In apple orchards, 'Ca. P. mali' can be transmitted by two psyllid species. Cacopsylla (Thamnopsylla) picta (Foerster, 1848) (syn. C. costalis) has been reported main vector in Germany (Jarausch et al., 2003, 2011) and northern Italy (Frisinghelli et al., 2000; Carraro et al., 2008), while Cacopsylla (Thamnopsylla) melanoneura
(Foerster, 1848) was identified as main vector in Aosta Valley (Tedeschi et al., 2002). C. picta is monophagous on Malus spp. and until now this species have been described only in Europe (Burckhardt, 1994; Ossiannilsson, 1992; Ouvrard, 2014) and Turkey (Klimaszewski and Lodos, 1977, 1979; Drohojowska and Burckhardt, 2014). C. melanoneura has a Palaearctic distribution and is oligophagous on Rosaceae, its principal host plant being a common shrub, hawthorn (Crataegus monogyna L.) (Ouvrard, 2014). In most of studied cases, both psyllid species are present in apple orchards (Jarausch et al., 2003; Delic et al., 2005; Carraro et al., 2008; Mattedi et al., 2008). Two others species living on hawthorn, Cacopsylla peregrina (Foerster, 1848) and Cacopsylla (Thamnopsylla) affinis (Low, 1880), were found able to harbor the phytoplasmas of the AP-group, in particular 'Ca. P. mali' (Tedeschi et al., 2009). Their transmission ability was not proven but this result highlights the potential role as vector of these psyllid species. In pear orchards, until recently, two psyllid species were known as vector of ' $\mathrm{Ca}$. $\mathrm{P}$. pyri'. Cacopsylla (Hepatopsylla) pyricola (Foerster, 1848) has been reported for Great Britain (Davies et al., 1992) and North America (Jensen et al., 1964), while Cacopsylla (Hepatopsylla) pyri (Linne, 1758) was described as the vector in France (Lemoine 1984), Italy (Carraro et al., 1998a) and Spain (Garcia-Chapa et al., 2005). C. pyri is widespread in Europe, in the Caucasus, Georgia, the Middle Asia, including Turkey (Klimaszewski and Lodos, 1979; Burckhardt and 
Hodkinson, 1986; Ossiannilsson, 1992; Burckhardt and Onuçar, 1993; Güçlü and Burckhardt, 1996; Ulubaş Serçe et al., 2006; Drohojowska and Burckhardt, 2014), while $C$. pyricola naturally occurs in the whole Palaearctic, from Europe to eastern Siberia, south Korea and Japan (Burckhardt and Hodkinson, 1986; Ossiannilsson, 1992; Inoue, 2010; Ouvrard, 2014) and was introduced into the eastern United States in the early 1800 s. The morphological identification of the Pyrus-feeding psyllids must be considered with a particular attention. In west Palaeartic, they form a complex of related but distinct seven species with overlapping geographical distributions (Ouvrard, 2014) and entomologists have usually applied names pyri or pyricola to all members of the complex and have failed to recognize morphological and biological differences between the species (Burckhardt and Hodkinson, 1986). Typically, Burckhardt and Onuçar (1993) have shown that the records of $C$. pyricola from Turkey (Klimaszewski and Lodos, 1977, 1979) were misidentifications and concerned Cacopsylla (Hepatopsylla) notata (Flor, 1861). Another uncertainty could be Cacopsylla chinensis (Yang and Li, 1981), a psyllid responsible of severe damages in pear orchards in Taiwan and China (Yang et al., 2004; Lee et al., 2008) and recently introduced in Japan (Katoh et al., 2013); comparisons of COX1 sequences prove that this species cannot be confused with the west Palaeartic C. pyri (Sauvion com. pers.). Others Pyrus-feeding psyllids have been still neglected as potential vectors of ' $\mathrm{Ca}$. P. pyri', in particular, Cacopsylla (Thamnopsylla) pyrisuga (Foerster, 1848) and Cacopsylla (Hepatopsylla) bidens (Šulc, 1907), two species reported from Turkey (Burckhardt and Hodkinson, 1986; Burckhardt and Onuçar, 1993; Ozgen et al., 2012; Drohojowska and Burckhardt, 2014).

The presence of fruit tree diseases caused by phytoplasma in Turkey was first reported in 1999 (Çağlayan and Gazel, 1999). Phytoplasma diseases have been reported in most of the germplasm sources and commercial orchards in the Mediterranean, Marmara and Central Anatolia regions (Sertkaya et al., 2005; Ulubaş Serçe et al., 2006; Gazel et al., 2007; Canik and Ertunç, 2007). Despite of the economic impact of these phytoplasma diseases, there is very few information on the vectors responsible of their spread. Only C. pyri individuals from Bursa collected on a local pear cultivar (cv. Deveci) were detected with AP-phytoplasma, and there are no data available on ' $\mathrm{Ca}$. P. mali' vectors in Turkey (Ulubaş Serçe et al., 2006). By a large scale sampling, this work highlights the different psyllid species present on apple, pear and wild host plants in Turkey and shows the potential spread risk of ' $\mathrm{Ca}$. P. pyri' and ' $\mathrm{Ca}$. P. mali' by several of these species.

\section{MATERIALS AND METHODS}

Sampling and identification of psyllids: Surveys were performed in the Eastern Mediterranean (Adana, Mersin,
Hatay and Kahramanmaraş), Marmara (Bursa and Yalova), Central Anatolia (Ankara and Niğde) and Eastern Anatolia (Malatya and Erzurum) regions where phytoplasma infections were previously reported and/or pome fruit growing is very important (Fig. 1). Psyllids were collected during 2010-2011 from cultivated, wild pome and stone fruit species (Malus spp., Pyrus spp., Crataegus spp. and Prunus spp.) in early spring and in overwintering sites on conifers (pine, fir, cedar) from late summer to autumn. They were captured using mouth exhausters and from $0.5 \mathrm{~m}^{2}$ white trays placed under tree branches that were then struck repeatedly. The psyllids were placed in different falcon tubes and labeled according to the host and province. Then, the insects were conserved in $95 \%$ alcohol at $4{ }^{\circ} \mathrm{C}$ for morphological and molecular analysis. For a correct identification of the specimens, different keys have been used: the handbooks published by Hodkinson and White (1979), and Ossiannilsson (1992); an electronic key focused on the Central European Cacopsylla spp. developing on Rosaceae (Burckhardt, 2007); and a short illustrated diagnoses of the adults of the three species associated with apple (Burckhardt and Lauterer, 2009). The differentiation of the both species C.melanoneura and C. affinis was problematic: females cannot be distinguished on morphology and the males could be discriminated only by observation of the apical part of the aedeagus and the shape of the parameres, yet these characters show inter-individual variability that could be source of errors. So, we have used the primers designed by Tedeschi and Nardi (2010) to tentatively discriminate the psyllids previously identified $C$. affinis or $C$. melanoneura by morphological characters, but unsuccessfully. Finally we gave up differentiating the two species and denoted them as the C.melanoneura-C. affinis complex.

PCR and RFLP analysis of phytoplasma from individual psyllids: Total DNAs were extracted from whole psyllids individually using the High-Salt method based on TNES (10 $\mathrm{mM}$ Tris, pH 7.5, $400 \mathrm{mM} \mathrm{NaCl}, 100 \mathrm{mM}$ EDTA, 0.6 \% SDS) buffer in semi-deep well plates (Peccoud et al., 2013). DNA was diluted in $60 \mu \mathrm{L}$ of sterile water and stocked at $-20^{\circ} \mathrm{C}$ before to be used for phytoplasma detection by PCR analysis. Phytoplasma-specific primers P1 5'AGAGTTTGATCCTGGCTCAGGA-3' (Deng and Hiruki, 1991) and P7 5'-CGTCCTTCATCGGCTCTT-3' (Smart et al., 1996) amplifying an approximately $1,800 \mathrm{bp}$ fragment were used for general identification of phytoplasma by conventional PCR. Nested PCR assays were employed using the universal primer pair for the AP group, F01 5'CGGAAACTTTTAGTTTCAGT-3' and R01 5'AAGTGCCCAACTAAATGAT-3', designed to amplify a 1,050 bp portion of the $16 \mathrm{~S}$ rRNA gene (Lorenz et al., 1995). Nucleic acid samples were diluted in sterile deionized water to obtain a final concentration of $20 \mathrm{ng} \cdot \mathrm{\mu L}^{-1}$. Conventional PCR and nested PCR reactions were performed in mixtures with $50 \mu \mathrm{L}$ final volumes containing $5 \mu \mathrm{L} 10 \times$ PCR buffer 
(100 mM Tris- $\mathrm{HCl} \mathrm{pH} 8.3,500 \mathrm{mM} \mathrm{KCl}, 0.01 \%$ gelatin) 1.5 $\mathrm{mM} \mathrm{MgCl}_{2}, 250 \mu \mathrm{M}$ each dNTP, 20 pmol. $\mu \mathrm{L}^{-1}$ each primer, 2 U Taq DNA polymerase (Fermentas, Vilnius, Lithuania) and $1 \mu \mathrm{L}$ DNA. Conventional PCR products were diluted to 1:50 and $1 \mu \mathrm{L}$ DNA was used for nested PCR. The following amplification conditions were used: first cycle $94^{\circ} \mathrm{C}$ for 2 min; 35 cycles $94^{\circ} \mathrm{C}$ for $1 \mathrm{~min}$ (30 $\mathrm{s}$ for nested PCR) denaturation, $55^{\circ} \mathrm{C}$ for $2 \mathrm{~min}$ ( $30 \mathrm{~s}$ for nested PCR) annealing, $72^{\circ} \mathrm{C}$ for $3 \mathrm{~min}$ ( $1 \mathrm{~min}$ for nested PCR) extension, and final cycle $72^{\circ} \mathrm{C}$ for $5 \mathrm{~min}$. Nested PCR products, including reference isolates of the phytoplasma $16 \mathrm{~S}$ rDNA sequence, were subjected to RFLP analysis. PCR products $(10 \mu \mathrm{L})$ were separately digested overnight at $37^{\circ} \mathrm{C}$ with restriction endonucleases $R s a \mathrm{I}$ and SspI (Fermentas). The digested products were analyzed by electrophoresis using $2 \%$ agarose gels, which were then stained with ethidium bromide. The products were visualized with an ultraviolet transilluminator and then photographed.

Phytoplasma-infected positive control plant materials (ESFY, AP and PD isolates) were kindly provided from Dr. B. Schneider (Germany).

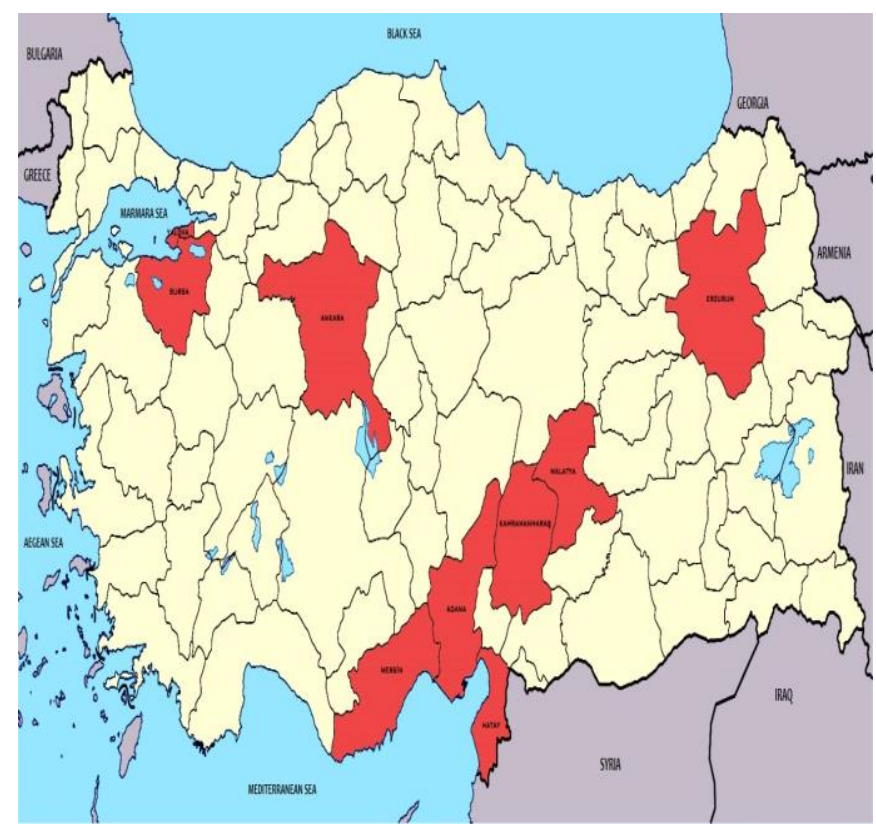

Figure 1.Surveyed provinces where potential psyllid vectors of apple proliferation and pear decline diseases were collected.

\section{RESULTS}

Psyllids were collected from Malus spp., Pyrus spp., Cydonia oblonga, as well as surrounding wild vegetation, mainly Crataegus spp., wild Pyrus spp. and some conifer species. The first Cacopsylla spp. individuals were found on hawthorn at the altitude of $950 \mathrm{~m}$ and on apple trees at the altitude of $1,390 \mathrm{~m}$. in the second half of April in Mersin province. In the fallow months, different Cacopsylla spp. was captured from cultured and wild forms of pome fruit trees in different provinces. Collected psyllids were identified morphologically as Cacopsylla crataegi (Schrank, 1801), C. picta, C. melanoneura-C. affinis complex, C. pyrisuga, C. pyri, $C$. pyricola and Cacopsylla spp. (Table 1).

C. picta individuals were collected from apple, pear and hawthorn plants in all sampling provinces and this was the most abundant species of psyllid. They were found only on apple trees in overwintering (OW) and new generation (NG) forms. C. melanoneura-C. affinis complex and C. crataegi were found only in the OW form on different wild and cultivated plants during the survey period.

C. pyri individuals were collected from pear, quince, apple and plum trees in the OW and NG forms. It was the most abundant Cacopsylla spp. among the possible vectors of PD disease. $C$. pyricola and $C$. pyrisuga were not as widespread as $C$. pyri in the sampling provinces.

A PCR analysis of these psyllids showed that the highest phytoplasma infection rate was in $C$. picta followed by $C$. pyri, C. melanoneura-C. affinis complex and C. crataegi with rates of $4.36,3.84,2.77$ and $1.67 \%$, respectively. No phytoplasma infection was detected in $C$. pyrisuga, $C$. pyricola or other uncharacterized Cacopsylla spp. (Table 1, Figure 2). Phytoplasma were detected in the OW and NG forms of different psyllid species but no phytoplasma were detected in any Cacopsylla spp. collected from conifers.

Phytoplasma-infected $C$. picta were only found in Mersin, which had a high psyllid incidence among the sampled provinces (Table 2). A similar correlation between the high psyllid population and the phytoplasma infection rate was also observed for $C$. melanoneura- $C$. affinis complex and $C$. crataegi, which were collected from different provinces.

RFLP profiles of PCR products from $C$. picta individuals and amplified by the F01-R01 primer pair exhibited ' $\mathrm{C} a$. P. mali' patterns. Interestingly, single ' $\mathrm{Ca}$. P. prunorum' and ' $\mathrm{Ca}$. P. pyri' RFLP profiles were obtained from the $C$. picta collected from an apple tree in Mersin province. One PCR amplicon obtained from a $C$. crataegi collected in Erzurum province also showed the ' $C a$. P. pyri' RFLP pattern (Figure 3). ' $C a$. P. pyri' was detected in $C$. pyri samples collected from pear and in five $C$. melanoneura-C. affinis complex collected from hawthorn and blackthorn trees. Interestingly, two $C$. pyri individuals exhibited ' $C a$. P. prunorum' profiles and one individual had a ' $C a$. P. mali' RFLP profile (Fig. 4,5; Table 3).

Cacopsylla pyri samples collected from plum, quince and apple trees were not infected by any phytoplasma. Among the phytoplasmas-infected psyllids, both genders had similar infection rates although more female psyllids were captured. 
Table 1. The Cacopsylla species collected from different provinces of Turkey and the phytoplasma infection rate in psyllids

\begin{tabular}{|c|c|c|c|c|c|c|c|c|}
\hline \multirow{2}{*}{$\begin{array}{l}\text { Collected Cacopsylla } \\
\text { species }\end{array}$} & \multirow[t]{2}{*}{ Province } & \multirow{2}{*}{$\begin{array}{l}\text { Plant } \\
\text { species }\end{array}$} & \multirow[t]{2}{*}{ Stage } & \multicolumn{4}{|c|}{ Infected/total tested } & \multirow{2}{*}{$\begin{array}{l}\text { Infection } \\
\text { rate }(\%)\end{array}$} \\
\hline & & & & Female & Male & Nymph & Total & \\
\hline \multirow{5}{*}{ C. picta } & Mersin & Apple & OW & $5 / 151$ & $5 / 112$ & 0 & $10 / 263$ & 3.80 \\
\hline & Mersin & Apple & NG & $2 / 33$ & $1 / 26$ & $1 / 3$ & $4 / 62$ & 6.45 \\
\hline & Mersin & Hawthorn & OW & $0 / 4$ & $1 / 4$ & 0 & $1 / 8$ & 12.50 \\
\hline & Bursa & Pear & OW & $0 / 3$ & $0 / 5$ & 0 & $0 / 8$ & 0 \\
\hline & Niğde & Apple & OW & $0 / 2$ & $0 / 1$ & 0 & $0 / 3$ & 0 \\
\hline Total & & & & & & & $15 / 344$ & 4.36 \\
\hline C. melanoneura- $C$. & Bursa & Wild plum & OW & $0 / 1$ & 0 & 0 & $0 / 1$ & 0 \\
\hline affinis & Bursa & Hawthorn & OW & $0 / 17$ & $0 / 6$ & 0 & $0 / 23$ & 0 \\
\hline \multirow[t]{7}{*}{ complex } & Bursa & Blackthorn & OW & $1 / 13$ & $1 / 10$ & 0 & $2 / 23$ & 8.69 \\
\hline & Bursa & Fir & OW & $0 / 20$ & $0 / 11$ & 0 & $0 / 31$ & 0 \\
\hline & Erzurum & Hawthorn & OW & $1 / 43$ & $1 / 35$ & 0 & $2 / 78$ & 2.56 \\
\hline & Hatay & Wild plum & OW & $0 / 2$ & 0 & 0 & $0 / 2$ & 0 \\
\hline & Hatay & Pine & OW & $0 / 2$ & 0 & 0 & $0 / 2$ & 0 \\
\hline & Hatay & Hawthorn & OW & $0 / 1$ & 0 & 0 & $0 / 1$ & 0 \\
\hline & Adana & Hawthorn & OW & $3 / 48$ & $0 / 43$ & 0 & $3 / 91$ & 3.29 \\
\hline Total & & & & & & & $7 / 252$ & 2.77 \\
\hline \multirow{8}{*}{ C. crataegi } & Hatay & Hawthorn & OW & $0 / 8$ & $0 / 10$ & 0 & $0 / 18$ & 0 \\
\hline & Hatay & Wild plum & OW & $0 / 1$ & 0 & 0 & $0 / 1$ & 0 \\
\hline & Hatay & Pine & OW & $0 / 9$ & $0 / 6$ & 0 & $0 / 15$ & 0 \\
\hline & Hatay & Cedar & OW & $0 / 1$ & $0 / 1$ & 0 & $0 / 2$ & 0 \\
\hline & Bursa & Blackthorn & OW & 0 & $0 / 1$ & 0 & $0 / 1$ & 0 \\
\hline & Erzurum & Hawthorn & OW & $1 / 9$ & $0 / 10$ & 0 & $1 / 19$ & 5.26 \\
\hline & Kahramanmaraş & Hawthorn & OW & $0 / 2$ & 0 & 0 & $0 / 2$ & 0 \\
\hline & Malatya & Hawthorn & OW & $0 / 1$ & $0 / 1$ & 0 & $0 / 2$ & 0 \\
\hline Total & & & & & & & $1 / 60$ & 1.67 \\
\hline \multirow{3}{*}{ C. pyrisuga } & Bursa & Hawthorn & OW & $0 / 1$ & 0 & 0 & $0 / 1$ & 0 \\
\hline & Bursa & Fir & OW & $0 / 1$ & 0 & 0 & $0 / 1$ & 0 \\
\hline & Erzurum & Pear & OW & $0 / 8$ & $0 / 4$ & 0 & $0 / 12$ & 0 \\
\hline Total & & & & & & & $0 / 14$ & 0 \\
\hline \multirow[t]{8}{*}{ C. pyri } & Adana & Quince & OW & $0 / 3$ & $0 / 1$ & 0 & $0 / 4$ & 0 \\
\hline & Ankara & Pear & OW & $1 / 37$ & $0 / 28$ & 0 & $1 / 65$ & 1.54 \\
\hline & Malatya & Pear & OW & $0 / 1$ & 0 & 0 & $0 / 1$ & 0 \\
\hline & Yalova & Pear & OW & $8 / 55$ & $2 / 26$ & $1 / 22$ & $11 / 103$ & 10.68 \\
\hline & Mersin & Plum & NG & $0 / 3$ & 0 & 0 & $0 / 3$ & 0 \\
\hline & Niğde & Apple & NG & 0 & $0 / 2$ & 0 & $0 / 2$ & 0 \\
\hline & Niğde & Pear & NG & $2 / 117$ & $1 / 78$ & 0 & $3 / 195$ & 1.54 \\
\hline & Bursa & Pear & OW & $2 / 45$ & $2 / 76$ & 0 & $4 / 121$ & 3.30 \\
\hline Total & & & & & & & $19 / 494$ & 3.84 \\
\hline \multirow{3}{*}{ C. pyricola } & Hatay & Pear & NG & $0 / 6$ & $0 / 5$ & 0 & $0 / 11$ & 0 \\
\hline & Hatay & Pine & OW & 0 & $0 / 1$ & 0 & $0 / 1$ & 0 \\
\hline & Adana & Quince & OW & $0 / 1$ & $0 / 1$ & 0 & $0 / 2$ & 0 \\
\hline Total & & & & & & & $0 / 14$ & 0 \\
\hline Cacopsylla & Malatya & Hawthorn & OW & $0 / 12$ & $0 / 4$ & 0 & $0 / 16$ & 0 \\
\hline \multirow{2}{*}{ spp. } & Malatya & Unknown & OW & $0 / 29$ & $0 / 11$ & 0 & $0 / 40$ & 0 \\
\hline & Malatya & Wild plum & OW & $0 / 3$ & 0 & 0 & $0 / 3$ & 0 \\
\hline Total & & & & & & & $0 / 59$ & 0 \\
\hline OVERALL TOTAL & & & & $26 / 693$ & $14 / 519$ & $2 / 25$ & $42 / 1237$ & \\
\hline
\end{tabular}

OW: Overwintered, NG: New generation 


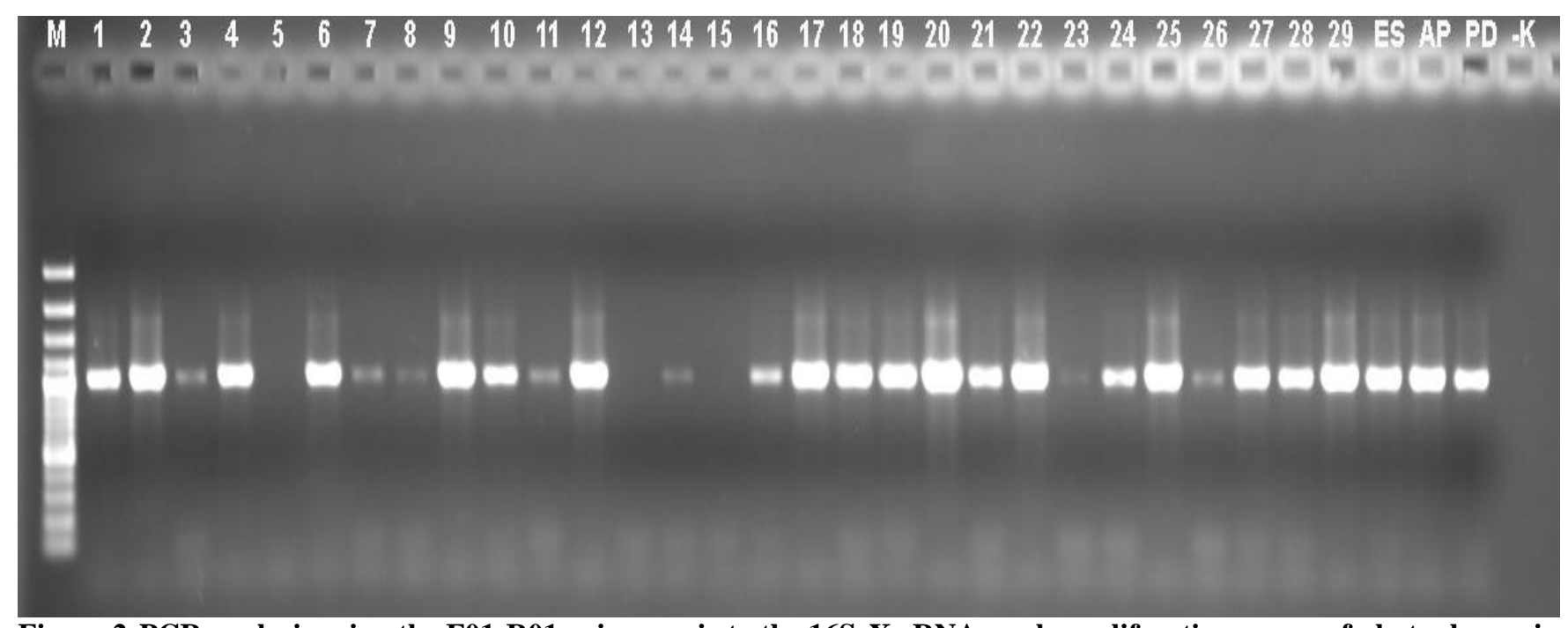

Figure 2. PCR analysis using the F01-R01 primer pair to the 16SrX rRNA apple proliferation group of phytoplasma in Cacopsylla picta (lines 1-13), Cacopsylla crataegi (lines 14-15), and Cacopsylla pyri (lines 16-29) DNAs. M, Gene Ruler DNA ladder mix (MBI Fermentas); ES, 'Candidatus Phytoplasma prunorum'; AP, 'Candidatus Phytoplasma mali' and PD, 'Candidatus Phytoplasma pyri' positive controls; and -K, water control.

Table 2. Prevalence of Cacopsylla species collected from different provinces of Turkey and their infection rates by apple proliferation phytoplasma group.

\begin{tabular}{|c|c|c|c|c|c|c|}
\hline \multirow[t]{3}{*}{ Provinces } & \multicolumn{6}{|c|}{ Collected psyllid species } \\
\hline & \multicolumn{2}{|c|}{ C. picta } & \multicolumn{2}{|c|}{$\begin{array}{c}\text { C. melanoneura - C.affinis } \\
\text { complex }\end{array}$} & \multicolumn{2}{|c|}{ C. crataegi } \\
\hline & Prevalance (\%) & Infec.rate (\%) & Prevalance (\%) & Infec.rate (\% & Prevalance (\%) & Infec.rate (\%) \\
\hline Mersin & 96.80 & 4.50 & - & - & - & - \\
\hline Bursa & 2.33 & 0.00 & 30.95 & 2.56 & 1.67 & 0.00 \\
\hline Niğde & 0.87 & 0.00 & - & - & - & - \\
\hline Hatay & - & - & 1.98 & 0.00 & 60.00 & 0.00 \\
\hline Adana & - & - & 36.11 & 3.29 & - & - \\
\hline Erzurum & - & - & 30.95 & 2.56 & 31.67 & 5.26 \\
\hline K.Maraş & - & - & - & - & 3.33 & 0.00 \\
\hline Malatya & - & - & - & - & 3.33 & 0.00 \\
\hline Total & 100 & 4.36 & 100 & 2.77 & 100 & 1.67 \\
\hline
\end{tabular}

-: no insect found

Table 3. The number of different Cacopsylla species carrying the phytoplasmas belonging to 16SrX group.

\begin{tabular}{lcccc}
\hline & $\begin{array}{c}\text { Ca. } \mathbf{P} \text {. } \\
\text { prunorum }\end{array}$ & $\boldsymbol{C a}$. P. mali & $\boldsymbol{C a}$. P. pyri & $\begin{array}{c}\text { Total numbers of } \\
\text { phytoplasma infected psyllids }\end{array}$ \\
\hline C. picta & 1 & 13 & 1 & 15 \\
C. melanoneura-C. affinis complex & 0 & 2 & 5 & 7 \\
C. crataegi & 0 & 0 & 1 & 1 \\
C. pyri & 2 & 1 & 16 & 19 \\
C. pyrisuga & 0 & 0 & 0 & 0 \\
C. pyricola & 0 & 0 & 0 & 0 \\
\hline
\end{tabular}




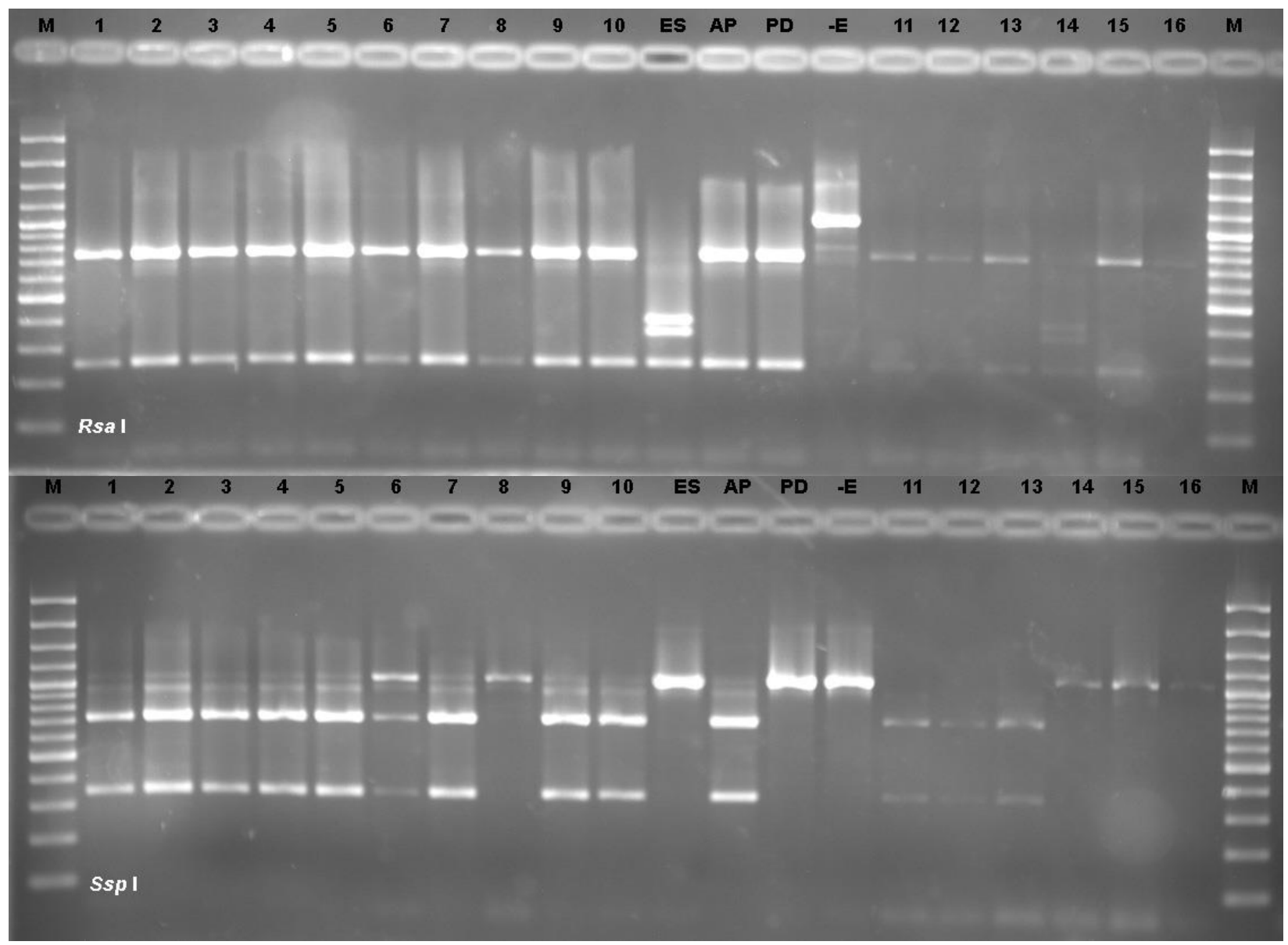

Figure 3. Restriction analysis, using RsaI and SspI restriction enzymes, of PCR amplicons generated by the F01-R01 primer pair to the $16 \mathrm{SrX}$ rRNA apple proliferation group of phytoplasma. The phytoplasma were isolated from Cacopsylla picta (lines 1-14, 16) and Cacopsylla crataegi (line 15). M, Gene Ruler DNA ladder mix (MBI Fermentas); ES, 'Candidatus Phytoplasma prunorum'; AP, 'Candidatus Phytoplasma mali' and PD, 'Candidatus Phytoplasma pyri’ positive controls; and -E, control without enzyme.

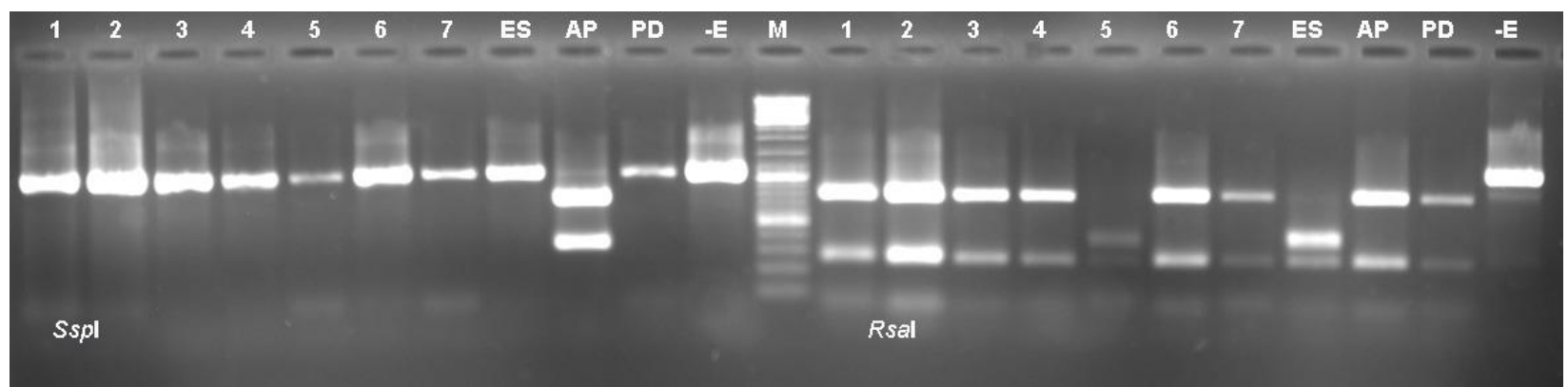

Figure 4. Restriction analysis, using $R s a I$ and $S s p I$ restriction enzymes, of PCR amplicons generated by the F01-R01 primer pair to the $16 \mathrm{SrX}$ rRNA apple proliferation group of phytoplasma. The phytoplasma were isolated from Cacopsylla melanoneura-C.affinis complex collected from hawthorn (lines $1,2,6$ ) and blackthorn (lines 3, 4) and Cacopsylla pyri collected from pear (lines 5, 7). M, Gene Ruler DNA ladder mix (MBI Fermentas); ES, 'Candidatus Phytoplasma prunorum'; AP, 'Candidatus Phytoplasma mali' and PD, 'Candidatus Phytoplasma pyri' positive controls; and -E, control without enzyme. 


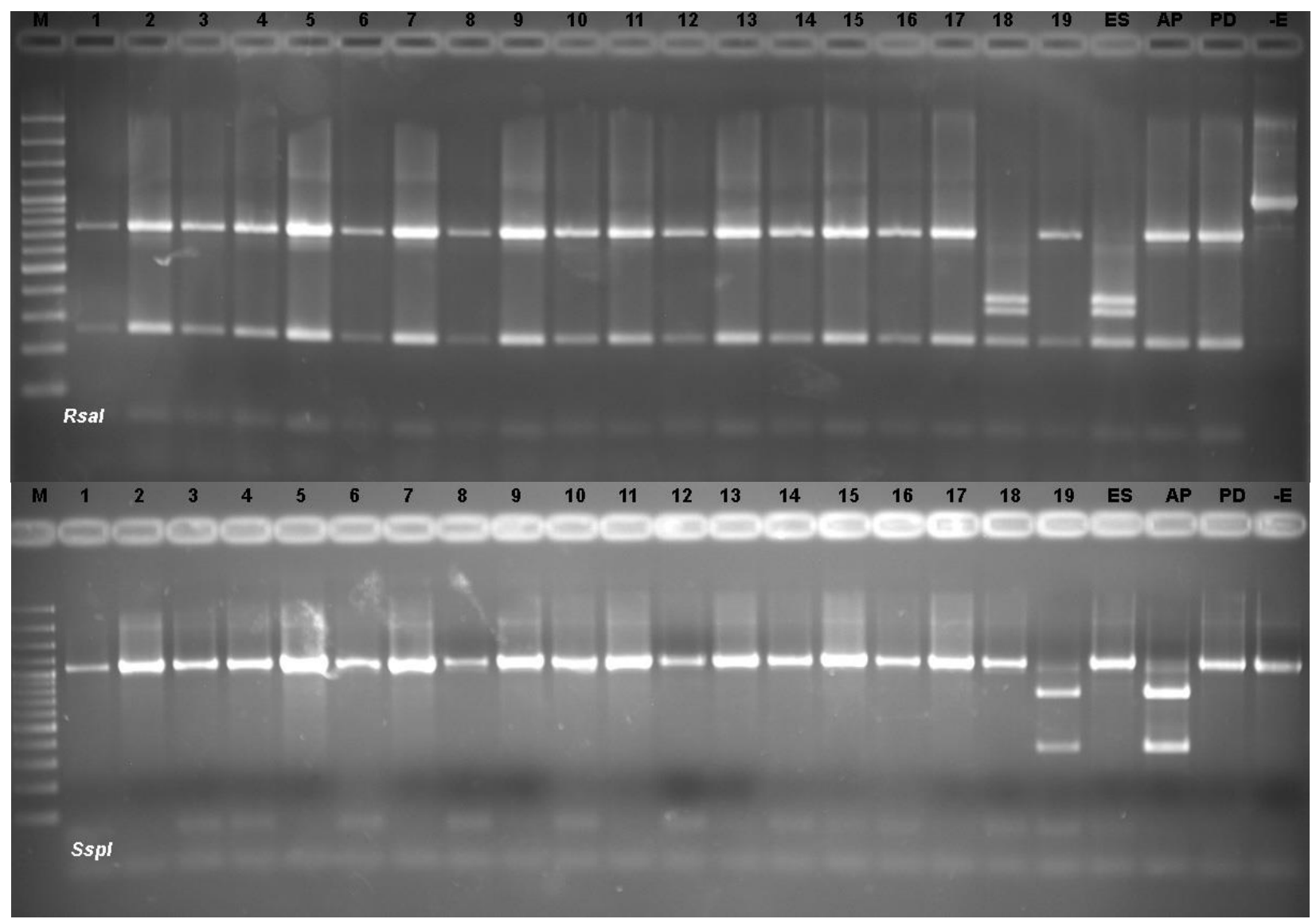

Figure 5. Restriction analysis, using RsaI and SspI restriction enzymes, of PCR amplicons from phytoplasma isolated from Cacopsylla pyri and generated by the F01-R01 primer pair to the 16SrX rRNA apple proliferation group of phytoplasma. The M, Gene Ruler DNA ladder mix (MBI Fermentas); ES, 'Candidatus Phytoplasma prunorum'; AP, 'Candidatus Phytoplasma mali' and PD, 'Candidatus Phytoplasma pyri' positive controls; and -E, control without enzyme.

\section{DISCUSSION}

In total five psyllid species, C. picta, C. crataegi, C. pyrisuga, C. pyri and $C$. pyricola and a psyllid complex of $C$. melanoneura-C. affinis, known as potential vectors of phytoplasmas that cause AP and PD diseases were collected from cultivated and wild varieties of stone and pome fruit trees as well as conifers in Turkey. There were already some reports on the presence and distribution of C. picta on Malus spp. (Klimaszewski and Lodos, 1977, 1979); $C$. pyri and $C$. pyricola on Pyrus spp., Malus spp. and Armeniaca vulgaris (Klimaszewski and Lodos, 1979; Burckhardt and Onuçar, 1993); C. affinis on Mespilus spp., Pyrus spp. and Crateagus spp. (Burckhardt and Onuçar 1993) and C. pyrisuga on Solanum melongena (Burckhardt and Hodkinson, 1986; Burckhardt and Onuçar, 1993). To our knowledge, until now there were no report on C. crataegi and C. melanoneura $-C$. affinis complex in Turkey.

Despite already being reported in Turkey, there was no detailed study on the Cacopsylla species as vectors. Most psyllid studies focused on C. pyri, which is a very important pest in the pear orchards of Turkey. These studies were mainly concerned with its life cycle, its tolerance to different pear cultivars and the biological management of this insect (Gençer, 1999; Yanik and Uğur, 2004; Erler, 2004a; Erler, 2004b). Studies related to $C$. pyri as a vector of PD disease were also recently reported (Gazel et al., 2007; Çağlayan et al., 2010). However, there have been no reports on the possible vectors of AP disease. In this study, the prevalence of different Cacopsylla species as potential vectors of AP in different hosts and provinces was reported for the first time.

The phytoplasma infection rate in C. pyri individuals in this study was fairly low at $3.84 \%$, whereas in a previous study in Turkey it was reported as $17.5 \%$ (Çağlayan et al., 2010). Additionally, the ' $\mathrm{Ca}$. P. pyri' infection rate was reported as $55 \%$ in C. pyri individuals in Italy (Carraro et al., 1998b; 2001). This difference may be because of different phytoplasma strains or pear cultivars in the two countries. 
Despite the widespread distribution of $C$. pyricola in Turkey (Lodos, 1986), the presence of C. pyricola and C. pyrisuga was very rare in the regions investigated in this study and no phytoplasma were detected in these insect species. Previously, naturally infected $C$. pyrisuga individuals were found by Kucerova et al. (2007), but their ability to transmit phytoplasma has not been proven until now (Jarausch and Jarausch, 2010). C. pyricola was described as the vector of PD in North America and England (Jensen et al., 1964; Hibino et al., 1971; Davies et al., 1992), while C. pyri is considered as the main vector in the rest of Europe (Carraro et al., 2001; Garcia-Chapa et al., 2005). Our present results seem to confirm these previous observations.

The phytoplasma infection rate in C. picta individuals varied according to their locations (provinces) and hosts. In our study, C. picta infection rate was $4.36 \%$ and this low rate could be correlated to the low incidence of AP disease in Turkey (Çağlayan et al., 2014). In Germany, the infection rate has been reported as 10\% in OW psyllids collected from apple orchards (Mayer et al., 2009) and a high infection rate of ' $\mathrm{Ca}$. P. mali' (40\%) in apple trees was detected (Bliefernicht and Krczal, 1995). The highest prevalence and infection rate for ' $C a$. P. mali' was found in C. picta individuals among the Cacopsylla spp. collected in the surveyed provinces. Although most of the $C$. picta individuals were infected by ' $\mathrm{Ca}$. P. mali', unexpectedly, single ' $\mathrm{Ca}$. P. prunorum' and 'Ca. P. pyri' RFLP profiles were obtained. Similarly, the RFLP analysis of amplified fragments from $C$. melanoneuraC. affinis complex individuals exhibited ' $C a$. P. mali' and 'Ca. P. pyri' profiles. C. melanoneura-C. affinis complex and C. crataegi showed only ' $C a$. P. pyri' profiles. Studies in different countries on $C$. melanoneura psyllids collected from hawthorn plants found they were infected by ' $\mathrm{Ca}$. P. pyri' as well as ' $C a$. P. mali' (Tedeschi et al., 2009; Tedeschi and Nardi, 2010). Out of 21 C. affinis psyllids collected from hawthorn in Italy, one has been reported as infected by ' $\mathrm{Ca}$. P. pyri' phytoplasma. In another study, ' $\mathrm{Ca}$. P. prunorum' was identified in C. affinis (Tedeschi et al., 2009; Tedeschi and Nardi, 2010). Even though some of the Cacopsylla spp. are specific to hosts, they might visit different hosts and acquire different phytoplasma species during feeding activity. According to our results, $C$. picta is a good candidate as a potential vector of ' $\mathrm{Ca}$. P. mali' in Turkey. However, other psyllids collected from apple and hawthorn were always found to be phytoplasmas free. This result was supported by a study from Germany that found the infection rate of $C$. melanoneura by ' $\mathrm{Ca}$. P. mali' was very low at $0.5-0.6 \%$ and the psyllid failed in both acquisition and transmission of this phytoplasma (Mayer et al., 2009).

Conclusion: In this study, it has been confirmed that $C$. pyri is the main vector of ' $C a$. P. pyri' and that $C$. picta is the main potential vector of ' $C a$. P. mali', which has been reported in Turkey for the first time. To give more data on the epidemiological aspect of diseases caused by phytoplasma, these results should be supported by experimental transmission trials.

Acknowledgement: The research was funded by the Partnership Hubert Curien, PHC-Bosphorus between TUBITAK-Turkey (Türkiye Bilimsel ve Teknolojik Araştırma Kurumu) and Campus France (French Minister of Foreign Affairs, campusfrance.org).

\section{REFERENCES}

Bliefernicht, K. and G. Krezal. 1995. Epidemiological studies on apple proliferation disease in Southern Germany. Acta Hort. 386:444-447.

Burckhardt, D. and I.D. Hodkinson. 1986. A revision of the west palaearctic pear psyllids (Hemiptera: Psyllidae). Bull. Entomol. Res. 76:119-132.

Burckhardt, D. and A. Önuçar. 1993. A review of Turkish jumping plant-lice (Homoptera, Psylloidea). Rev. Suisse Zool. 100:547-574.

Burckhardt, D. 1994. Psylloid pests of temperate and subtropical crop and ornamental plants (Hemiptera, Psylloidea): A review. Entomol. Tren. Agric. Sci. 2:173186.

Burckhardt, D. 2007. Pictorial key of Central European Cacopsylla species associated with Rosaceae. Available online at http://www.psyllidkey.com

Burckhardt, D. and P. Lauterer. 2009. Taxonomy of psyllids (Hemiptera, Psylloidea) associated with apple and stone fruits in Central and Southern Europe. Bull. Soc. Entomol. 82:253-257.

Canik, D. and F. Ertunç. 2007. Distribution and molecular characterization of apple proliferation phytoplasma in Turkey. Bull. Insectol. 60:335-336.

Carraro, L., N. Loi, P. Ermacora, A. Gregoris and R. Osler. 1998a. Transmission of pear decline by using naturally infected Cacopsylla pyri. Acta Hort. 472:665-668.

Carraro, L., R. Osler, N. Loi, P. Ermacora and E. Refatti. 1998b. Transmission of European stone fruit yellows phytoplasma by Cacopsylla pruni. J. Plant Pathol. 80:233-239.

Carraro, L., R. Osler, N. Loi, P. Ermacora and E. Refatti. 2001. Fruit tree phytoplasma diseases diffused in nature by psyllids. Acta Hort. 550:345-350.

Carraro, L., F. Ferrini, G. Labonne, P. Ermacora and N. Loi. 2008. Infectivity of Cacopsylla picta (syn. Cacopsylla costalis), vector of 'Candidatus Phytoplasma mali' in north east Italy. Acta Hort. 781:403-407.

Çağlayan, K. and M. Gazel. 1999. Primary studies for viroid and phytoplasma problems of stone fruits in East Mediterranean Area of Turkey. J. Plant Pathol. 83:45-49.

Çağlayan, K., M. Gazel, Ç. Ulubaş Serçe and F. Can. 2010. Experimental transmission trials by Cacopsylla pyri, 
collected from pear decline infected orchards in Turkey. Julius-Kühn-Archiv. 427:171-174.

Çağlayan, K., M. Gazel, Ç. Ulubaş Serçe and K. Kaya. 2014. Türkiye'de bazı meyve ağaçlarında saptanan fitoplazmalar ve olası vektörleri. Proc. $\mathrm{V}^{\text {th }}$ Plant Protection Congress of Turkey, 3-5 February 2014, Antalya; (Abstract), pp.190.

Davies, D.L., C.M. Guise, M.F. Clark and A.N. Adams. 1992. Parry's disease of pears is similar to pear decline and is associated with mycoplasma-like organisms transmitted by Cacopsylla pyricola. Plant Pathol. 41:195-203.

Delic, D., M. Martini, P. Ermacora, L. Carraro and A. Myrta. 2005. First report of fruit tree phytoplasmas and their psyllid vectors in Bosnia and Erzegovina. J. Plant Pathol. $87: 150$.

Deng, S. and C. Hiruki. 1991. Genetic relatedness between two non-culturable mycoplasmalike organisms revealed by nucleic acid hybridization and polymerase chain reaction. Phytopathology 81:1475-1479.

Drohojowska, J. and D. Burckhardt. 2014. The jumping plantlice (Hemiptera: Psylloidea) of Turkey: A checklist and new records. Turk. J. Zool. doi:10.3906/zoo-1307-15.

Erler, F. 2004a. Bazı Armut Çeşitlerinin Armut Psyllidi, Cacopsylla pyri (L.) (Hom., Psyllidae)' ye Duyarlılık Düzeyleri. Akdeniz Üniv. Ziraat Fak. Derg. 17:121-125.

Erler, F. 2004b. Natural enemies of the pear psylla Cacopsylla pyri in treated vs. untreated pear orchards in Antalya, Turkey. Phytoparasitica 32:295-304.

Frisinghelli, C., L. Delaiti, M.S. Grando, D. Forti and M.E. Vindiman. 2000. Cacopsylla costalis (Flor 1861), as a vector of apple proliferation in Trentino. J. Phytopathol. 148:425-431.

Garcia-Chapa, M., J. Sabate, A. Lavina and A. Battle. 2005. Role of Cacopsylla pyri in the epidemiology of pear decline in Spain. Eur J. Plant Pathol. 111:9-17.

Gazel, M., Ç. Ulubaş Serçe, K. Çağlayan and H. Öztürk. 2007. Detection of 'Candidatus Phytoplasma pyri' in Turkey. Bull. Insectol. 60:125-126.

Gençer, N.S. 1999 Bursa ilinde armutlarda zarar yapan Cacopsylla (Homoptera: Psyllidae) türleri üzerinde biyolojik ve ekolojik araştırmalar. Ph.D Thesis, Uludağ Üniv. Fen Bilimleri Enst. Doktora Tezi, p.97.

Güçlü, Ş. and D. Burckhardt. 1996. New records of jumping plant-lice (Hemiptera, Psylloidea) from Turkey. Entomofauna 17:381-384.

Hibino, H., G.H. Kaloostian and H. Schneider. 1971. Mycoplasma like bodies in the pear psylla vector of pear decline. Virology 43:34-40.

Hodkinson, I.D. and I.M. White. 1979. Homoptera Psylloidea. In: A. Watson (ed.), Handbooks for the identification of British insects, Vol. II, Part 5(a). Royal Entomol Soc London, London, UK, p.101.
Inoue, H. 2010. The generic affiliation of Japanese species of the subfamily Psyllinae (Hemiptera: Psyllidae) with a revised checklist. J. Nat. Hist. 44:333-360.

Jarausch, B., N. Schwind, W. Jarausch, G. Krezal, E. Muler and E. Dickler. 2003. First report of Cacopsylla picta as a vector for apple proliferation phytoplasma in Germany. Plant Dis. 87:101.

Jarausch, B. and W. Jarausch. 2010. Psyllid vectors and their control. In: J. Weintraub and P. Jones (eds.), Phytoplasmas: Genomes, Plant Hosts and Vectors. CAB International, Wallingford, UK, pp.250-271.

Jarausch, B., N. Schwind, A. Fuchs and W. Jarausch. 2011. Characteristics of the spread of apple proliferation by its vector Cacopsylla picta. Phytopathology 101:14711480.

Jensen, D.D., W.H. Griggs, C.Q. Gonzales and H. Schneider. 1964. Pear decline virus transmission by pear psylla. Phytopathology 54:1346-1351.

Katoh, H., H. Inoue, F. Kuchiki, Y. Ide, N. Uechi and T. Iwanami. 2013. Identification of a distinct lineage of Cacopsylla chinensis (Hemiptera: Psyllidae) in Japan on the basis of two mitochondrial DNA sequences. J. Econ. Entomol. 106:536-542.

Klimaszewski, S.M. and N. Lodos. 1977. New information about jumping plant lice of Turkey (Homoptera: Psylloidea). Ege Üniv. Ziraat Fak. Derg. 14:1-9.

Klimaszewski, S.M. and N. Lodos. 1979. Further data about jumping plant lice of Turkey (Homoptera, Psylloidea). Türkiye Bitki Koruma Dergisi .Turk. J. Plant Prot. 3: 316.

Kucerova, J., L. Talacko, P. Lauterer, M. Navratil and R. Fialova. 2007. Molecular tests to determine Candidatus Phytoplasma pyri presence in psyllid vectors from a pear tree orchard in the Czech Republic- a preliminary report. Bull. Insectol. 60:191-192.

Lee, H.C., M.M. Yang and W.B. Yeh. 2008. Identification of two invasive Cacopsylla chinensis (Hemiptera: Psyllidae) lineages based on two mitochondrial sequences and restriction fragment length polymorphism of cytochrome oxidase I amplicon. J. Econ. Entomol. 101:1152-1157.

Lemoine, J. 1984. Is Psylla pyri a vector of pear decline in France? Bulletin-SROP 7: 245-251.

Lorenz, K.H., B. Scheineder, U. Ahrens and E. Seemuller. 1995. Detection of apple proliferation and pear decline phytoplasmas by PCR amplification of ribosomal and nonribosomal DNA. Phytopathology 85:771-776.

Lodos, N. 1986. Türkiye Entomolojisi Cilt II (Genel, Uygulamal, Faunistik) Ege Üniv. Ziraat Fak. Yay. No: 429, İzmir, Turkey, p.580.

Mattedi, L., F. Forno, C. Cainelli, M.S. Grando and W. Jarausch. 2008. Research on 'Candidatus Phytoplasma mali' transmission by insect vectors in Trentino. Acta Hort. 781:369-374. 
Mayer, C.J., B. Jarausch, W. Jarausch, W. Jelkmann, A. Vilcinskas and J. Gross. 2009. Cacopsylla melanoneura has no rellevance as a vector of apple proliferaiton in Germany. Phytopathology 99:729-738.

Mehle, N., J. Brzin, J. Boben, M. Hren, J. Frank, N. Petrovic, K. Gruden, T. Dreo, I Zezlina, G. Seljak and M. Ravnikar. 2007. First report of Candidatus Phytoplasma mali in Prunus avium, P. armenica and P. domestica. Plant Pathol. 56:721.

Ossiannilsson, F. 1992. The Psylloidea (Homoptera) of Fennoscandia and Denmark. In: Brill EJ (ed) Fauna Entomologica Scandinavica, Vol. 26. Leiden, Netherlands, p.346.

Ouvrard, D. 2014. Psyl'list - The World Psylloidea Database. Available online at http://www.hemipteradatabases.com/psyllist/

Ozgen, I., C. Gözüaçık and D. Burckhardt. 2012. Contribution to the knowledge of Psylloidea (Hemiptera) of Southeastern Anatolia, Turkey. Sixth European Hemiptera Congress, Blagoevgrad, Bulgaria, 25-29 June 2012.

Peccoud, J., G. Labonne and N. Sauvion. 2013. Molecular test to assign individuals within the Cacopsylla pruni complex. PLoS ONE 8(8): e72454. doi:10.1371/journal.pone.0072454

Seemüller, E. and B. Schneider. 2004. 'Candidatus Phytoplasma mali', 'Candidatus Phytoplasma pyri' and 'Candidatus Phytoplasma prunorum', the causal agents of apple proliferation, per decline and European stone fruit yellows, respectively. In. J. Syst. Evol. Microbiol. 54:1217-1226.

Seemüller, E., L. Carraro, B. Jarausch and B. Schneider. 2011a. Apple Proliferation Phytoplasma. In: A. Hadidi, M. Barba, T. Candresse and W. Jelkmann (eds.), Virus and Virus-Like Diseases of Pome and Stones Fruits. The American Phytopathological Society, St. Paul, Minnesota, USA, pp.67-76.

Seemüller, E., B. Schneider and B. Jarausch. 2011b. Pear Decline Phytoplasma. In: A. Hadidi, M. Barba, T. Candresse and W. Jelkmann (eds.), Virus and Virus-Like Diseases of Pome and Stones Fruits. The American
Phytopathological Society, St. Paul, Minnesota, USA, pp.77-84.

Sertkaya, G., M. Martini, P. Ermacora, R. Musetti and R. Osler. 2005. Detection and characterisation of phytoplasmas in diseased stone fruits and pear by PCRRFLP analysis in Turkey. Phytoparasitica 33: 380-390.

Smart, C.D., B. Schneider, C.L. Blomquist, L.J. Guerra, N.A. Harrison, U. Ahrens, K.H. Lorenz, E. Seemuller and B.C. Kirkpatrick. 1996. Phytoplasma-specific PCR primers based on sequences of 16S-23SrRNA spacer region. Appl. Environ. Microb. 62:2988-2993.

Tedeschi, R., D. Bosco and A. Alma. 2002. Population dynamics of Cacopsylla melanoneura (Homoptera: Psyllinae), a vector of Apple proliferation phytoplasma in northwestern Italy. J. Econ. Entomol. 95:544-551.

Tedeschi, R., P. Lauterer, L. Brusetti, L. Tota and A. Alma. 2009. Composition, abundance and phytoplasma infection in the hawthorn psyllid fauna of Northwestern Italy. Eur. J. Plant. Pathol. 123:301-310.

Tedeschi, R. and F. Nardi. 2010. DNA-based discrimination and frequency of phytoplasma infection in the two hawthorn-feeding species, Cacopsylla melanoneura and Cacopsylla affinis, in northwestern Italy. Bull. Entomol. Res. 100:741-747.

Ulubaş Serçe, Ç., M. Gazel, K. Çağlayan, M. Bas and L. Son. 2006. Phytoplasma diseases of fruit trees in germplasm and commercial orchards in Turkey. J. Plant Pathol. 88:179-185.

Weintraub, P.G. and L. Beanland. 2006. Insect Vectors of Phytoplasmas. Ann. Rev. Entomol. 51:91-111.

Yang, C. and F. Li. 1981. The pear psylla (Homoptera: Psyllidae) of China with descriptions of 7 new species. Entomotaxonomia 3:35-47.

Yang, M.M., J.H. Huang and F. Li. 2004. A new record of Cacopsylla species (Hemiptera Psyllidae) from pear orchards in Taiwan. Formosan Entomol. 24:213-220.

Yanık, E. and A. Uğur. 2004. Avc1 böcek Anthocoris nemoralis (F.) (Heteroptera: Anthocoridae)'in laboratuvar ve doğa şartlarında Cacopsylla pyri (L.) (Homoptera: Psyllidae) ve Ephestia kuehniella Zell. (Lepidoptera: Pyralidae) yumurta tüketimi. Bitki Koruma Bülteni 44:47-67. 